\title{
RESEARCH OF MICROREGION-RELATED RENEWABLE ENERGY TENDERS FOR LOCAL GOVERNMENTS
}

\author{
Andras Szeberenyi, Arpad Papp-Vary \\ Budapest Metropolitan University, Hungary \\ aszeberenyi@metropolitan.hu, apappvary@metropolitan.hu
}

\begin{abstract}
Green energy plays an increasingly important role nowadays, and its importance is being addressed worldwide. Polluting and irresponsible energy-wasting behaviour can lead to the depletion of natural resources in the long run, therefore the use of alternative energy sources instead of fossil fuels is the focus of attention. The current situation suggests that a very swift change in lifestyle would be necessary to be able to protect the remaining natural resources. The aim of the representative primary research was to assess and examine the use and application possibilities of green and renewable energy in all the twenty-five municipalities in the micro-region of Gyöngyös, Hungary. The topics of environmental protection, attitudes towards an environmentally conscious lifestyle and environmental sustainability were also important areas of the research. In addition to processing and analysing the literature, the questionnaire and in-depth interview as primary research was carried out with results of previous field research. The obtained results reveal that in the case of the municipalities, the energy gained by the sun (e.g., solar panels) can be used most efficiently, followed by biomass. These are mostly used in municipal buildings, mayoral offices and health centres. Developments and investments related to renewable energy have been implemented to a significant extent from national or European Union tender sources. The amount of planned renewable energy investments in the future is expected to be mainly between 10-25 million HUF (roughly 2750069000 EUR) in the case of smaller municipalities, and more than 100 million HUF (276000 EUR) in the case of bigger local governments. $60 \%$ of the surveyed municipalities support the use of renewable energy at local level, while $24 \%$ do not, and a further $16 \%$ are unaware of such activities. $76 \%$ of local governments know about and support renewable energy investments affecting the population, such as the installation of solar panels and solar collectors.
\end{abstract}

Keywords: green energy, environmental awareness, renewable energy, local government, renewable energy related national and EU tender.

\section{Introduction}

Green energy plays an increasingly important role in our lives. The subject of alternative energy sources and environmental protection has become a hot topic around the world. By choosing renewable energy sources, consumers support the development of clean energy that reduces the environmental impact of conventional energy production and increases energy independence [1]. Environmental awareness therefore goes beyond the awareness of the environment through concrete actions, as it seeks to create the most appropriate long-term environmental interests for society and its members [2]. In this context, the objectives of the Europe 2020 strategy also play an important role in promoting environmental and sustainability factors [3].

The problem we raise is that polluting and irresponsibly energy-wasting behaviour lead to the exhaustion of natural resources in the long run, therefore alternative energy sources should become the focus of attention instead of fossil fuels [4]. This is also emphasized by the European Union, thus applying more consistent regulations and tax benefits in order to spread technologies that promote renewable natural resources $[5 ; 6]$.

It is also worth mentioning two other processes, which are going on in the European Union and belong to the topic of environmental problems: there are an increasing number of underdeveloped regions which are losing their attractiveness for investment (including green and renewable energy investments as well), having to face the issue of poor infrastructure, ageing and underqualified population as more and more people tend to move to urban areas (or SMART Cities) in the hope of finding better quality of life, better expertise, job opportunities and a greater possibility to live in a greener and cleaner environment $[7 ; 8]$. These are problems that all countries face, and Hungary is an integral part of this, especially when it comes to the use of renewable energy tenders [9].

This is one of the main reasons that our preliminary research results were necessary, because the findings highlighted that there is a great need to examine municipalities in connection with the topic, as they play a leading role in towns and villages, therefore, they can be considered a significant research factor. In addition, they provide significant guidance to local residents, for example, on how to use renewable energy and their efforts to improve environmental protections. 
Based on the preliminary literature, our own practical experience and preliminary research, we sought to confirm/reject the following hypotheses:

Hypothesis 1: Local governments play a very important role in influencing the environmental awareness and environmental attitudes of the population in the study area.

Hypothesis 2: Territorial and rural development programmes/tenders help achieve the environmental objectives of the European Union at the level of the examined region.

Hypothesis 3: $\quad$ The examined local governments have limited opportunities in terms of waste management; therefore, they cannot support environmental protection at a local level.

The aim of the representative primary research is therefore to present the attitude of the municipalities at a micro-region level and the possibilities of their development with the help of tenders regarding renewable energy, as well as their future tenders and ones that had already been implemented.

The questionnaires were filled out by the deputies, notaries and mayors of 25 local governments in person - depending on who could provide more specific information regarding the research questions. The individual visits made it possible to conduct an extended, interview-based survey, where additional useful information was shared by the interviewed municipal leaders. The planned number of interviews was carried out as expected, because at least one person from each local government took part in the research.

The questionnaire was divided into topics, which primarily covered the general and targeted use of renewable energy. It also surveyed the sources and amounts of such investments in the case of municipalities (if there were any) and examined what additional opportunities they had to apply for relevant tenders. One of its parts also contains the issues of waste collection, its management and the possibility factors of local governments supporting environmental protection at a local level.

\section{Materials and methods}

Hungary is divided into 9 different regions. There are 3 counties in the Northern Hungary region, of which Heves County was the focus of our research. The county is divided into 7 micro-regions (Bélapátfalva, Eger, Füzesabony, Gyöngyös, Hatvan, Heves, Pétervására), of which the micro-region of Gyöngyös was chosen for our study. [10]. The size of the micro-region is $751 \mathrm{~km}^{2}$ and its population is 69,833 [11]. The local governments of all 25 settlements in the micro-region participated in the research, therefore the results can be considered fully representative. The part of the research presented by us in this study was realised between the time interval 2018/2019.

As several settlements operate merged local governments due to the size of the villages, their structure can be categorized according to three types. The first includes towns that have separate local governments, of which there are two. The second group consists of villages that have separate local governments, of which there are twelve. The third group includes villages that do not have a separate local government, of which there are eleven.

The questionnaire was prepared for local governments and consisted of 23 questions, the first part of which surveyed the forms of using renewable energy sources, the implementation of their sources, and the extent of investments and tenders in this connection. In the second part of the questionnaire, we covered soil and water quality, methods of selective waste collection, air quality during the heating season, attitudes towards local environmental protection and support for renewable energy.

Three different research questions were formulated in connection with our primary research:

- the first question is related to the position and role of local governments in terms of environmental awareness;

- the second is connected to the possibilities of contributing to the prevention and solution of environmental problems locally;

- the third question is about the main factors of the examined municipalities related to environmental awareness and protection.

The logical framework of the research is presented in Table 1. 
Logical framework of the research

\begin{tabular}{|l|l|l|}
\hline \multicolumn{1}{|c|}{ Research objective } & \multicolumn{1}{|c|}{ Research question } & \multicolumn{1}{c|}{ Research method } \\
\hline $\begin{array}{l}\text { The study of municipalities - as a } \\
\text { key target group for rural and } \\
\text { regional development - in the micro- } \\
\text { region of Gyöngyös (Hungary) along } \\
\text { the topics of renewable energy, } \\
\text { environmental awareness and } \\
\text { environmental protection. }\end{array}$ & $\begin{array}{l}\text { Q1: What is the position and role of } \\
\text { local governments in terms of } \\
\text { environmental awareness? }\end{array}$ & $\begin{array}{l}\text { Q2: How is it possible to contribute } \\
\text { Qurvey }(N=25), \\
\text { to the prevention and solution of } \\
\text { descriptive } \\
\text { statistics, content } \\
\text { analysis (regarding } \\
\text { open-ended } \\
\text { the level of municipalities)? }\end{array}$ \\
$\begin{array}{l}\text { Q3: What can be the main factors of } \\
\text { the examined municipalities related } \\
\text { to environmental awareness and } \\
\text { protection? }\end{array}$ & \\
\hline
\end{tabular}

Note. "Q" stands for the number of research questions. " $N$ " stands for the number of local governments that participated in the primary research. Source: Own research

\section{Results and discussion}

In the first question of the survey for local governments we wanted to know whether the municipalities or institutions maintained by them use any of the renewable energy sources we had listed, and if so, which type they use and where they use it. In the case of the 25 local governments surveyed, the three energy sources indicated in Table 2 are used, especially biomass and solar energy.

Possible responses also included geothermal, hydropower and wind power, but none of these were used by the municipalities at the time of the primary research. During the personal interviews, the respondents repeatedly highlighted that the energy that can be used most efficiently is energy gained from the sun (especially through solar panels), followed by biomass. One of the reasons emphasized by them was the location of the villages, as they are located close to the Mátra Mountains, the highest mountain range in Hungary with a maximum elevation at 1,014 meters, therefore the benefits of altitude can be better utilized and sunshine duration is adequate. The results obtained also highlight that biomass is mostly used in municipal buildings, mayor's offices, health care centres, kindergartens, schools, integrated community and service spaces, and doctor's offices - in one case, it was even used in a castle.

Renewable energy sources used by the municipalities involved in the research - distribution by place of use

\begin{tabular}{|c|c|c|}
\hline Type of energy source & \multicolumn{2}{|l|}{ Place of use } \\
\hline Biomass & $\begin{array}{ll}\text { - } & \text { primary and secondary schools } \\
\text { - } & \text { mayor's offices } \\
\text { - } & \text { gymicipal buildings } \\
\text { - } & \text { integrated community spaces }\end{array}$ & $\begin{array}{l}\text { - } \text { kindergartens } \\
\text { - } \text { castle } \\
\text { - } \text { doctor's offices } \\
\text { - } \text { health care } \\
\text { - centres } \\
\text { - } \text { service spaces } \\
\end{array}$ \\
\hline Biogas & \multicolumn{2}{|l|}{$\begin{array}{ll}\text { - } & \text { wastewater treatment plants } \\
\text { - } & \text { halls of swimming pool buildings }\end{array}$} \\
\hline Solar & \multicolumn{2}{|c|}{$\begin{array}{l}\text { - } \begin{array}{l}\text { solar panels in kindergarten and primary school buildings } \\
\text { - solar panels and solar collectors in municipal buildings for } \\
\text { water heating }\end{array} \\
\end{array}$} \\
\hline Not using & \multicolumn{2}{|l|}{ - $20 \%$ of the local municipalities } \\
\hline
\end{tabular}

Note. In the case of the presented research results, the number of participants is hereinafter indicated by the letter " $N$ ". Source: Own research, $\mathrm{N}=25$ 
We also examined the sources that the local governments used to implement these developments and investments. Due to the nature of the open-ended question, respondents were able to mention multiple grant sources. As mentioned above, 20 local governments participated in tender-supported investments regarding renewable energy, therefore Fig. 1 only shows the distribution of these local governments. Based on the results obtained, the 20 municipalities implemented a total of 35 renewable energy investments, which were categorized as follows: [12;13]:

1) European Union tender source (23\%) in the case of 8 municipalities; 2) KEHOP (Environment and Energy Operational Programme) tender source (14\%) in the case of 5 municipalities; 3) TOP (Territorial and Settlement Development Operational Programme) tender source (9\%) in the case of 3 municipalities; 4) National tender source (34\%) in the case of 12 municipalities; 5) Municipality sources (20\%) in the case of 7 municipalities.

The developments and investments related to renewable energy were implemented from some Hungarian tender source (e.g., Széchenyi 2020) to a significant extent (34\% - see Fig. 1). The percentage of the funding was $70-90 \%$, and municipalities had to cover the remaining 10-30\% from their own resources. If the municipality cannot comply with the specifications provided in the tender documentation during the evaluation process, not only will they have to reimburse the tender amount, but the municipality may also expect an additional penalty.

The European Union source was the second most used tender source (in about 23\%), which allowed $100 \%$ application support in several cases, for example in the settlements Mátraszentimre and Nagyréde. This also fully covered other costs such as finding professionals, installing and maintaining solar panels, managing mandatory periodic check-ups or warranty problems, etc. In terms of forms of financing, own municipal resources accounted for $20 \%$ of all tenders, mostly in terms of biomass and the modernisation of heating technology. The combined use of tender sources also appeared, for example in the case of Markaz (TOP 3.2.1-16 + use of own resources) Gyöngyös (EU + KEHOP + domestic tenders + own resources) and Vámosgyörk (EU + KEHOP + own resources), where interdependent or - in some cases - complementary renewable energy tender projects were implemented.

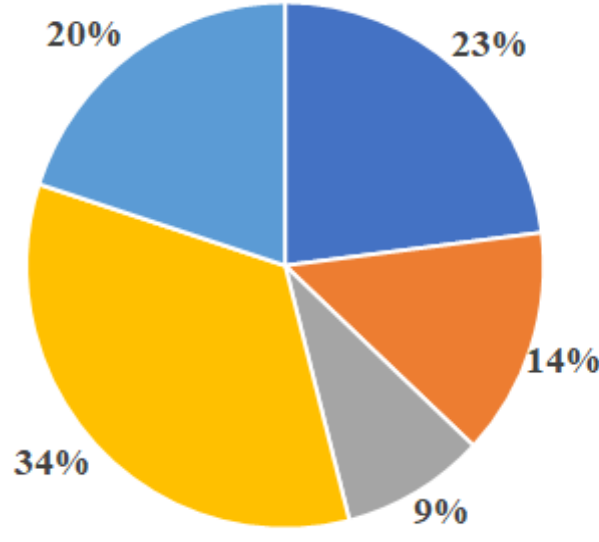

- European Union tender source

- KEHOP tender source

n T OP tender source

n National tender source

- Source of local goverment

$N=\mathbf{2 0}$

Fig. 1. Distribution of tender funds used by the interviewed municipalities (\%), source: Own research

The primary research also surveyed how long it takes for these investments to pay off, according to the municipalities, defined at the level of annual savings. Based on the results, 5\% of the municipalities claim that it takes less than 2 years for the investment to pay off. $20 \%$ think that the amount invested in developments will pay off in about 2-3 years, which can be considered a more realistic data in the case of biomass and biogas (and also in the case of solar energy, if it operates very efficiently). Most municipalities (about 35\%) believe that it will take about 4-5 years for the investment to pay off, which is already closer to the real duration in the case of solar energy, but in order for it to happen, outstanding sunshine duration and a proper storage for the generated electricity is needed.

The next question examined the average amount of tender investments, the distribution of which is shown in Fig. 2. The question was defined according to six categories, five of which include some amount, while the sixth option is "no investment planned", but this is not relevant for the figure. 
In the case of 20 participating local governments, the result includes the amount of money per municipality, divided into five categories in the examined period of January 2018 to December 2019.

Based on the figure, it can be stated that in the case of $40 \%$ of the local governments that participated, the extent of investment was less than 10 HUF million (27500 EUR), which includes 8 local governments. There was a slightly larger investment in the case of $30 \%$ of the local governments, which meant an investment amount of more than 10 HUF million (27500 EUR) but less than 25 million HUF (69000 EUR). In the case of $15 \%$, the extent of investments and developments was more than 25 million HUF (69000 EUR), but less than 50 million HUF (138000 EUR), and in the case of another 10\% it was a relatively high amount, which meant more than 50 million HUF (138000 EUR), but less than 100 million HUF (276000 EUR). There was only one municipality that exceeded the total value of 100 million HUF (276000 EUR) as total investment budget.

In several cases, factors of problems related to the question were mentioned, which highlighted the lack of the municipalities' own financial resources. Another raised problem was the financing problems related to public procurement (lack of own contribution); the lack of professionals and supervisory bodies already mentioned above (e.g. it cannot be an energy producer or it can only be an energy producer if certain criteria are met); in the case of solar panels already installed, there is no professional who can check them regularly; accounting difficulties arising during the tender, subsequent funding deficit; the repair or replacement of already installed but defective devices and panels under suitable conditions is in many cases only partially possible or not possible at all; the process is usually very long and cumbersome, which in many cases can take weeks, months, or in more drastic cases even 1 year; and during the maintenance period, the municipalities are obliged to provide annual reports to the managing authority, which involves several additional administrative tasks.

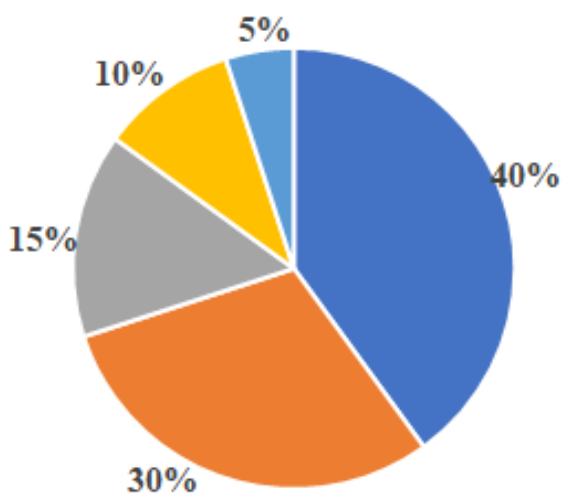

- Less than HUF 10 million (EUR 27,500)

- More than HUF 10 million (EUR 27,500) but less than HUF 25 million (EUR 69,000)

- More than HUF 25 million (EUR 69,000) but less than HUF 50 million (EUR 138,000)

" More than HUF 50 million (EUR 138,000) but less than HUF 100 million (EUR 276,000)

- More than HUF 100 million (EUR 276,000)

$$
N=20
$$

Fig. 2. Distribution of the average amount of real investments in the case of the examined local governments in the period of 2018-2019 (\%), source: Own research

The planning of future investments in renewable energy also includes the approximate amount of investments planned by the surveyed municipalities. We also addressed this in a separate question, in which case the municipalities could choose from 6 different categories -5 categories included a specific amount, and a "no investment planned" option was included, but this was not indicated by any of the municipalities, suggesting that all of them plan some kind of investment in renewable energy. The division of the categories and the amounts planned by the municipalities of corresponding settlements are shown in Table 3.

It is clear from the obtained results that a significant part of the local governments in the microregion of Gyöngyös plan to invest more than 25 million HUF (more than 69000 EUR) in renewable energy sources from 2020. It is interesting to compare that the size of the settlements and the number of 
people living there differ significantly in many cases - for example, in 2019 Gyöngyös (the largest town in the micro-region) had a population of 29036, while Visonta (one of the smallest villages) had a population of 1,250. Still, both settlements plan to invest more than 100 million HUF (more than 276000 EUR). One of the possible reasons for this is the presence of the Mátra Power Plant in Visonta, which, in any case, is an advantage for the settlement in tenders. It seems typical that most of the smaller villages with a population of less than 3000 are planning investments of less than 10 million HUF (less than 27500 EUR). During the oral interviews, one of the problems emphasized by the mayors was the lack of own contribution, significantly limiting the effectiveness of participation in tenders. Another problem is that some tenders are interlinked - therefore, as long as they do not implement the first level, they cannot apply for the next investment, thus blocking the success of the process.

Table 3

\section{Extent of the municipalities' planned future investments in terms} of renewable energy sources, source: own research

\begin{tabular}{|l|l|}
\hline Extent of planned investments & \multicolumn{1}{c|}{ Local governments belonging to the municipality } \\
\hline Less than 10 million HUF & $\begin{array}{l}\text { Adács, Atkár, Domoszló, Halmajugra, Kisnána, } \\
\text { Ludas, Nagyfüged, Visznek }\end{array}$ \\
\hline $\begin{array}{l}\text { More than } 10 \text { million HUF but } \\
\text { less than } 25 \text { million HUF }\end{array}$ & $\begin{array}{l}\text { Gyöngyösoroszi, Gyöngyöstarján, Karácsond, } \\
\text { Markaz, Szücsi, Vécs }\end{array}$ \\
\hline $\begin{array}{l}\text { More than } 25 \text { million HUF but } \\
\text { less than 50 million HUF }\end{array}$ & $\begin{array}{l}\text { Abasár, Gyöngyöshalász, Gyöngyöspata, } \\
\text { Mátraszentimre, Pálosvörösmart }\end{array}$ \\
\hline $\begin{array}{l}\text { More than 50 million HUF but } \\
100 \text { million HUF }\end{array}$ & Detk, Nagyréde \\
\hline More than 100 million HUF & $\begin{array}{l}\text { Gyöngyös, Gyöngyöstarján, Gyöngyössolymos, } \\
\text { Vámosgyörk, Visonta }\end{array}$ \\
\hline No investment planned & \\
\hline
\end{tabular}

We have examined several issues related to waste collection and its management, of which the following are worth mentioning. Some municipalities have limited opportunities in terms of waste management, but this does not prevent local governments from supporting environmental protection at a local level. Table 4 shows how and at what level municipalities support this, divided into four different factors. The table also includes municipalities that do not support local environmental protection. It was possible to indicate multiple factors to answer this question.

Table 4

Factors of the examined municipalities with a focus on environmental protection, source: Own research, $N=25$

\begin{tabular}{|l|l|}
\hline \multicolumn{1}{|c|}{ Factors } & \multicolumn{1}{c|}{ Settlements } \\
\hline $\begin{array}{l}\text { Kindergartens, primary and secondary schools in the } \\
\text { settlement also support it through garbage collection and } \\
\text { environmental protection programmes (green } \\
\text { kindergarten/school), which also contribute to the conscious } \\
\text { education of children. }\end{array}$ & $\begin{array}{l}\text { Abasár, Gyöngyös, } \\
\text { Gyöngyössolymos, Markaz, } \\
\text { Nagyréde, Pálosvörösmart, Szücsi, } \\
\text { Vámosgyörk, Visonta, Visznek }\end{array}$ \\
\hline $\begin{array}{l}\text { The local population of the settlement pay special attention to } \\
\text { environmental protection, which is also supported and } \\
\text { financed by local governments - for example, by creating a } \\
\text { special environmental protection fund. }\end{array}$ & $\begin{array}{l}\text { Detk, Gyöngyös, Karácsond, } \\
\text { Markaz, Mátraszentimre, } \\
\text { Nagyréde, Pálosvörösmart, } \\
\text { Vámosgyörk }\end{array}$ \\
\hline $\begin{array}{l}\text { They join national programs and tenders and organise } \\
\text { garbage collection campaigns to encourage the population to } \\
\text { change their attitudes. }\end{array}$ & $\begin{array}{l}\text { Abasár, Gyöngyös, Gyöngyöspata, } \\
\text { Gyöngyössolymos, } \\
\text { Gyöngyöstarján, Mátraszentimre, } \\
\text { Nagyfüged, Nagyréde, } \\
\text { Pálosvörösmart, Vámosgyörk, } \\
\text { Visonta }\end{array}$ \\
\hline They do not support local environmental protection. & $\begin{array}{l}\text { Atkár, Adács, Domoszló, } \\
\text { Gyöngyöshalász, Gyöngyösoroszi, } \\
\text { Halmajugra, Kisnána, Ludas, Vécs }\end{array}$ \\
\hline
\end{tabular}


The first factor in the table mostly concerns kindergartens and schools, which contribute to the conscious education of children through garbage collection and environmental programmes. According to the results obtained, this factor is typical of $40 \%$ of the municipalities (and the settlements they belong to). The second factor is characterizing $32 \%$ of the municipalities and mainly concerns the local population. The third factor concerns national programmes, tenders and the planning of garbage collection campaigns, with which they would like to encourage the population to change their attitude as soon as possible. This factor is most characteristic of the settlements surveyed, as $44 \%$ of them said it was important. The last factor characterizes settlements that are unable to support local environmental protection for some reason (e.g., financing problems). This factor affects $36 \%$ of the settlements, which is a significant number in our opinion, as more than a third of the district's settlements do not contribute to environmental protection in this sense.

\section{Conclusions}

Summarising the research results, the following answers to the research questions and hypotheses can be given:

Based on the results obtained in the case of the first research question - examining the position and role of local governments in terms of environmental awareness - it can be concluded that the local governments play a relatively significant role in the use of renewable energy sources at local level. One proof of this is that $80 \%$ of the local governments that participated in the representative primary research use biomass, biogas and solar energy in several places like primary and secondary schools, mayor's offices, municipal buildings, community spaces and health care centres. These have been implemented through various tenders (e.g., the European Union tenders, KEHOP tenders, but mostly national tenders), and in $45 \%$ of cases the majority of investments were between HUF 10 million HUF (HUF 27500 HUF) and 50 million HUF (138000 EUR). Therefore, we consider the first hypothesis justified.

The second research question was about how the local governments can contribute to the prevention and solution of environmental problems locally. Although we have only been able to present a smaller part of our research, it is clear from these results that the future priority of local governments is to invest in renewable energy tenders as much as possible. Local government leaders who participated in the research repeatedly emphasised that this will be their main focus in the future as well. Because of these results we consider the second hypothesis partially justified. To give an example the results of the research show that four fifths of the municipalities' typically small but still implemented investments related to renewable energy were based on area/rural development sources. In this respect, the contribution of the programmes in question can be demonstrated after all. If we also consider the result that municipal actions and investments related to the topic have an impact on increasing the environmental awareness of the population, the contribution of the programmes to the environmental goals of the European Union (and Hungary) cannot be refuted. In view of this, the synchronization of tender systems and opportunities with the results, the increased support of municipalities, and the use of online communication systems are strongly recommended.

The third research question was related to the main factors of the examined local governments in connection with environmental awareness and protection. The primary research showed that although there are local governments that have limited opportunities in terms of waste management, this does not prevent them from supporting environmental protection at local level. Three relevant factors were identified (1) garbage collection and environmental protection programmes, 2) creating special environmental protection fund, 3) joining national programmes and tenders - organise garbage collection campaigns to encourage the population to change their attitudes), which can support environmental awareness. More importantly, several of the local governments examined use more than one factor. In connection to this research question, the third hypothesis - which was that the examined local governments have limited opportunities in terms of waste management, therefore they cannot support environmental protection at a local level - is rejected.

Although local governments are trying to make the most of their limited possibilities, there are still many settlements that are unable to contribute to local environmental protection. For these reasons, it is certainly worthwhile to continue research in this direction. 


\section{References}

[1] Hilary F. Vanishing Borders: Protecting the Planet in the Age of Globalization, World Watch Institute, 2000, $257 \mathrm{p}$.

[2] Kerekes S., Szlávik J. A környezeti menedzsment közgazdasági eszközei, ("Economic Tools of Environmental Management") Complex Kiadó, Budapest, 2003, 280 p. (In Hungarian)

[3] Szabó M., Kiss Á., Effects of renewable energy resources on the landscape, Hungarian Geographical Bulletin 63(1), 2017, pp. 5-16.

[4] Takács-György K., Domán Sz., Tamus A., Horská E., Palková Z. What do the youth know about alternative energy sources - case study from Hungary and Slovakia, Visegrad Journal on Bioeconomy and Sustainable Development 4(2), 2015, pp. 36-41.

[5] Szamek G., Az EU klímavédelmi törekvései, különös tekintettel az Európa 2020 stratégiára és Párizsra, ("The climate protection efforts of the EU, in particular the Europe 2020 strategy and Paris") Közép-Európai Közlemények 10(2), 2017, pp. 182-195. (In Hungarian)

[6] Čeryová D., Bullová T., Turčeková N., Adamičková I., Moravčíková D., Bielik P. Assessment of the renewable energy sector performance using selected indicators in european union countries, Resources 9(9) 102, 2020, ISSN 2079-9276.

[7] Nagy H., Káposzta J., Varga-Nagy A. Is ICT smartness possible development way for Hungarian rural areas? Engineering for Rural Development, 17, 2018, pp. 463-468

[8] Némedi-Kollár K., Káposzta J., Péli L. A SMART kezdeményezések alkalmazhatóságának vizsgálata Magyarországon, Studia Mundi Economica 4(4), 2017, pp. 29-37. (In Hungarian)

[9] Káposzta J., Ritter K., Nagy H. Local economic development in transition economies: A tool for sustainable development of rural areas, Global Perspectives on Trade Integration and Economies in Transition, 2016, pp. 281-298.

[10] Szeberényi A., Environmentally conscious lifestyle analysis among high school and university students in a Hungarian rural town of the Heves County, Visegrad Journal on Bioeconomy and Sustainable Development 6(2), 2017, pp. 74-78.

[11]National Spatial Development and Spatial Planning Information System (TeIR), [online] [17.01.2021] Available at: https://www.teir.hu/helyzet-ter-kep/, 2021

[12] EU applications - GKF development, available at http://unios-palyazatok.gkf.hu/, 2019, downloaded: 15th January 2021

[13] Pálné Kovács I., Modellváltás a Magyar önkormányzati rendszerben, [ref.] Jakab A., Gajduschek Gy, (edited) A magyar jogrendszer állapota. Budapest: MTA Társadalomtudományi Kutatóközpont, Jogtudományi Intézet, 2016. pp. 583-599. (In Hungarian) 